\title{
A New Enzymatic Process for the Treatment of Phenolic Pollutants
}

\author{
Mauri Sergio Alves Palma ${ }^{1}$, Harald Horn ${ }^{2}$, Mario Zilli ${ }^{3}$, Gisele Pigatto ${ }^{1,3}$ and Attilio \\ Converti $^{3}$ \\ ${ }^{1}$ Departamento de Tecnologia Bioquímico-Farmacêutica; Faculdade de Ciências Farmacêuticas; Universidade de \\ São Paulo; 05508-000; São Paulo - SP - Brasil. ${ }^{2}$ Institute of Water Quality Control; Technical University of \\ Munich; 85748; Garching - Germany. ${ }^{3}$ Department of Civil, Chemical and Environmental Engineering; University \\ of Genoa;16145; Genoa - Italy
}

\begin{abstract}
This work aimed to develop a new economic enzymatic process to treat the phenolic pollutants using pure tyrosinase in stirred vessel and adopting temperature $(T), p H$, rotational speed $(N)$, initial phenol $\left(C_{P, o}\right)$ and enzyme $\left(C_{T}\right)$ concentrations as independent variables. Experimental data of the residual phenol concentration $\left(C_{P}\right)$ were used to calculate the oxidation efficiency $(\eta)$, initial oxidation rate $\left(-r_{o}\right)$ and time required to reach the end of reaction $(t)$ that were selected as the responses. Under the optimal conditions $\left(T=45^{\circ} \mathrm{C}, \mathrm{pH} 6.6, \mathrm{~N}=400 \mathrm{rpm}, \mathrm{C}_{P, o}=100 \mathrm{ppm}\right.$ and $\left.C_{T}=50 \mathrm{U} / \mathrm{mL}\right), \eta$ was $88.1 \%,-r_{o}=10.2 \mathrm{mg} \mathrm{L}^{-1} \mathrm{~min}^{-1}, t=40 \mathrm{~min}$. These results suggested that tyrosinase-rich crude extracts from vegetable byproducts could be quite promising.
\end{abstract}

Key words: phenols, tyrosinase, wastes, enzymatic treatment

\section{INTRODUCTION}

Phenol and other phenolic compounds are common constituents of wastewaters from various activities in different industrial sectors such as electrolytic strip tin coating, chemical (polymeric resins, bisphenol A, alkyl phenols, caprolactams, adipic acid, etc.), petrochemical (oil refining), metallurgical (smelting, iron, steel, and coke), pharmaceutical, textile, plastics, explosive, coffee, ceramic, paint, varnish and pesticide productions (Rosatto et al. 2001). Phenols released into the environment may directly or indirectly cause serious health and odor problems. They can in fact inhibit the growth, or exert lethal effects to aquatic organisms even at relatively low concentrations (5 to $25 \mathrm{mg} / \mathrm{l}$, depending on the temperature and state of maturity of the organism), and impart off flavors in drinking water and food processing wastewater (Theodore et al. 1997). Due to these constraints, the Brazilian legislation is very restrictive on phenols discharge, and the maximum concentration allowed in the treated effluents is 0.5 ppm (Conselho Nacional do Meio Ambiente 2005). Eleven of these compounds are among the 129 major pollutants present in the list of the Environmental Protection Agency (Shibata and Palma 2009). Most of the overall world production of phenol, which was $7.7810^{6}$ tons in 2001 , has been used for the syntheses of bisphenol A (39\%), phenolic resins (27\%), caprolactam (16\%), alkylphenols (5\%), 2,6-xylenol (3\%), anilines (2\%), and others (8\%) (Anonymous 2002).

Various techniques are available for the treatment of phenolic effluents at different concentrations,

*Author for correspondence: converti@unige.it 
but one should take into consideration that industrial effluents have very complex composition, and a specific treatment would be needed for each particular effluent (Freire et al. 2000). The treatment of phenolic effluents can be subdivided into two main categories, the destruction and the recovery methods (Britto and Rangel 2008). Among the destruction methods, there are biological treatments (Freire et al. 2000), incineration, ozonation in the presence of UV radiation, oxidation with wet air (Britto and Rangel 2008) and electrochemical oxidation (Mojović et al. 2009). The recovery methods include liquid-liquid extraction (Jiang et al. 2003a, b; Palma et al. 2007, 2010), adsorption and electro-adsorption with activated charcoal (Ayranci and Conway 2001; Jain et al. 2002), ion exchange with resins, membrane processes such as a pervaporation, and extraction with membrane, supported liquid membrane and liquid membrane in emulsion (Kujawski et al. 2004).

Taking into account these issues, there is the need to develop a new, ecological and auto-sustainable way for the treatment of phenolic effluents. A promising process appears to be the enzymatic oxidation (Durán and Esposito 2000; Faria et al. 2007), particularly by polyphenol oxidase (PPO) that is more commonly referred to as tyrosinase (Martin et al. 2008; Romanovskaya et al. 2009; Yamada et al. 2009). Another enzyme equally efficient in the oxidation of phenols is the polyphenol peroxidase (Campeanu et al. 1999), but it has the disadvantage of requiring hydrogen peroxide instead of atmospheric oxygen as a substrate (Ikehata and Nicell 2000a, b; LópezMolina et al. 2003). Tyrosinase, which is present in many fruits, vegetables, seafood and mushrooms, is responsible for the browning of fruits when they have their internal tissue exposed to oxygen. It is a tetrameric enzyme with molecular weight of $120 \mathrm{kDa}$, two active sites, each containing one copper, and the highest activity at $\mathrm{pH}$ in the range 5.0-8.0. It is usually obtained from mushroom and used in biosensors for phenols detection (Faria et al. 2007; Ikehata and Nicell 2000a, b). Several fruits and vegetables have been used to obtain PPO, which include artichoke (López-Molina et al. 2003), wheat grain (Fuerst et al. 2006), apple (Eidhin et al. 2006), pawpaw (Fang et al. 2007), loquat fruit (SellésMarchart et al. 2006) and banana (Wuyts et al. 2006). The reactions of phenols oxidation catalyzed by tyrosinase can be summarized as follows (Quan et al. 2004).

Phenol $+1 / 2 \mathrm{O}_{2} \rightarrow$ Catechol

Catechol $+1 / 2 \mathrm{O}_{2} \rightarrow o$-Quinone $+\mathrm{H}_{2} \mathrm{O}$

But similar mechanisms are followed for other phenols such as $o$-cresol and $p$-nitrophenol. The use of this enzyme is of particular interest because it oxidizes phenols to oligomers similar to melanins and imparts a brown color to the reaction medium, making it possible to quantify in real time the degradation of phenolic compounds.

The aim of this study was to investigate the kinetics and efficiency of phenols oxidation as well as the time to reach the end of reaction, so as to apply this process for the treatment of polluted wastewaters. However, since the use of pure tyrosinase in the treatment of effluents would be uneconomical, further effort has to be made to obtain crude extracts of this enzyme from the vegetables as cheap -albeit less active- catalysts (Kameda et al. 2006).

\section{MATERIALS AND METHODS}

\section{Chemicals}

Chemicals used in this study were tyrosinase T3824-25KU (5370 U/mg) and 4-aminoantipyrine from Sigma-Aldrich (São Paulo, Brazil), and phenol, $o$-cresol, $p$-nitrophenol, $\mathrm{K}_{2} \mathrm{HPO}_{4}, \mathrm{KH}_{2} \mathrm{PO}_{4}$ and $\mathrm{H}_{3} \mathrm{PO}_{4}$ of analytical grade from Labsynth Ltda (Diadema-SP, Brazil). Distilled water was used in the experiments.

\section{Equipment}

Figure 1 illustrates the experimental set-up used to study the oxidation of phenols in aqueous solution by tyrosinase. It was carried out as described by Quadros and Baptista (2003) using a standard Rushton mixed vessel described in detail in previous work (Palma et al. 2007, 2010; Shibata and Palma 2009). Briefly, the mixed glass reactor (R) with 1.0 L-working volume was provided with an external jacket for temperature regulation by a water bath (B) $\left(0<T<60^{\circ} \mathrm{C}\right)$ and four holes to host the mixing device (M) (100-1500 rpm), a thermometer $(\mathrm{T})$, a syringe for sampling $(\mathrm{S})$ and a funnel for feeding either phenol or enzyme buffer solution $(\mathrm{F})$. It was also provided with a valve (V) located in the reactor bottom to allow aqueous phase discharge. An air pump (P) provided the oxygen necessary for the enzymatic reaction. 


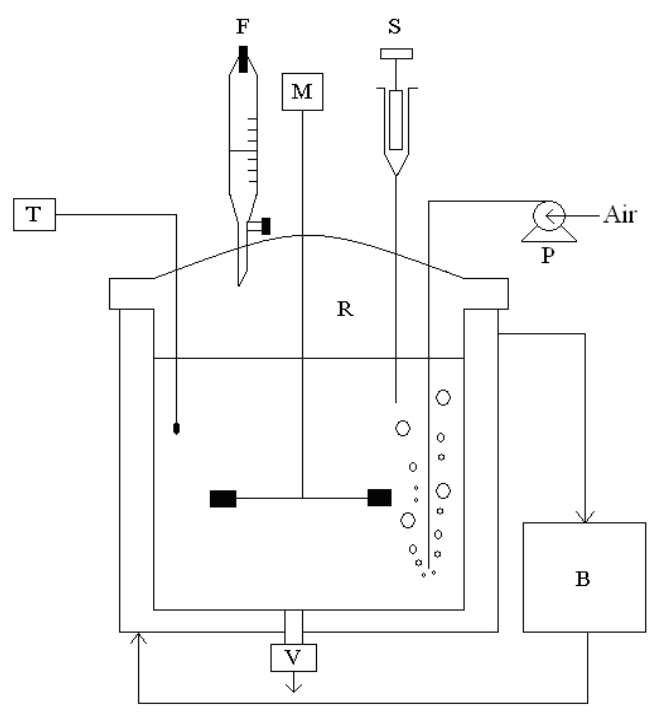

Figure 1 - Experimental set-up used to study the oxidation of phenols in aqueous solution by tyrosinase. M: mixer; B: thermostatic bath; F: funnel; R: reactor; S: syringe; T: thermometer; V: valve; P: pump.

\section{Phenols Oxidation Tests}

Batch oxidation tests were performed by adding into the reactor, under mixing at given rotational speed, $0.5 \mathrm{~L}$ of $0.05 \mathrm{M}$ phosphate buffer solution having the desired $\mathrm{pH}$ and containing the selected phenolic pollutant. After reaching the selected temperature, $3.0 \mathrm{~mL}$ of $0.05 \mathrm{M}$ phosphate buffer solution ( $\mathrm{pH}=6.6$ ) containing 25,000 U tyrosinase were added in the shortest time as possible through a separation funnel, and a chronometer started measuring the reaction time.
Table 1 shows the experimental conditions under which the tests of phenols oxidation were carried out together with the main results obtained at the end of reaction. The end of reaction was determined by linear fitting of the experimental data and, progressively, omitting the initial points. When the slope of the resulting straight line became lower than $10^{-2}$, the time corresponding to the first remaining datum was assumed to be that needed to reach the end of reaction.

Table 1 - Experimental conditions and results at equilibrium of phenols oxidation tests.

\begin{tabular}{|c|c|c|c|c|c|c|c|c|}
\hline Run & $T\left({ }^{\circ} \mathbf{C}\right)^{\mathrm{a}}$ & pH & $N(\mathbf{r p m})^{b}$ & $C_{T}(\mathrm{U} / \mathrm{mL})^{\mathrm{c}}$ & $C_{P, o}(\mathrm{ppm})^{\mathrm{d}}$ & $t(\min )^{\mathrm{e}}$ & $\eta(\%)^{\mathrm{f}}$ & $-r_{o}\left(\mathrm{mg} \mathrm{L}^{-1} \min ^{-1}\right)^{\mathrm{g}}$ \\
\hline 1 & 15 & 6.6 & 400 & 50 & 100 & $>500$ & $\sim 77$ & 0.96 \\
\hline 2 & 25 & 6.6 & 400 & 50 & 100 & 100 & 88.5 & 4.0 \\
\hline 3 & 35 & 6.6 & 400 & 50 & 100 & 80 & 88.2 & 3.7 \\
\hline $4^{\mathrm{h}}$ & 45 & 6.6 & 400 & 50 & 100 & 40 & 88.1 & 10.2 \\
\hline 5 & 55 & 6.6 & 400 & 50 & 100 & 25 & 30.9 & 2.0 \\
\hline 6 & 45 & 5.6 & 400 & 50 & 100 & 120 & 74.8 & 9.2 \\
\hline 7 & 45 & 7.6 & 400 & 50 & 100 & 40 & 89.1 & 7.3 \\
\hline 8 & 45 & 6.6 & 200 & 50 & 100 & 50 & 69.3 & 6.1 \\
\hline 9 & 45 & 6.6 & 300 & 50 & 100 & 40 & 85.3 & 10.2 \\
\hline 10 & 45 & 6.6 & 500 & 50 & 100 & 30 & 83.0 & 9.5 \\
\hline 11 & 45 & 6.6 & 600 & 50 & 100 & 50 & 71.8 & 8.1 \\
\hline 12 & 45 & 6.6 & 800 & 50 & 100 & $>200$ & $\sim 65$ & 7.1 \\
\hline 13 & 45 & 6.6 & 400 & 25 & 100 & 50 & 78.3 & 4.6 \\
\hline 14 & 45 & 6.6 & 400 & 75 & 100 & 70 & 95.3 & 9.7 \\
\hline 15 & 45 & 6.6 & 400 & 50 & 50 & 30 & 73.0 & 2.0 \\
\hline 16 & 45 & 6.6 & 400 & 50 & 200 & 50 & 61.9 & 14.4 \\
\hline 17 & 45 & 6.6 & 400 & 50 & 400 & 50 & 52.0 & 10.2 \\
\hline $18^{\mathrm{i}}$ & 45 & 6.6 & 400 & 50 & 100 & 40 & 91.8 & 7.2 \\
\hline $19^{\mathrm{j}}$ & 45 & 6.6 & 400 & 50 & 100 & 30 & 85.6 & 10.4 \\
\hline
\end{tabular}

${ }^{\mathrm{a}}$ Temperature; ${ }^{\mathrm{b}}$ Rotational speed; ${ }^{\mathrm{c}}$ Enzyme concentration; ${ }^{\mathrm{d}}$ Initial pollutant concentration; ${ }^{\mathrm{e}}$ Time to reach the end of reaction; ${ }_{\mathrm{f}}^{\mathrm{f}}$ Oxidation efficiency; ${ }^{\mathrm{g}}$ Initial reaction rate; ${ }^{\mathrm{h}} \mathrm{Best}$ conditions determined in this study; ${ }^{\mathrm{i}}$ Test performed using $o$-cresol; ${ }^{\mathrm{j}} \mathrm{Test}$ performed using $p$-nitrophenol. 
The phenolics (phenol, $o$-cresol and $p$-nitrophenol) and the temperature, $\mathrm{pH}$ and initial phenols concentration were selected from those usually reported for the treatment of phenol emissions in Brazil $\left(15 \leq T \leq 55^{\circ} \mathrm{C} ; 5.6 \leq \mathrm{pH} \leq 7.6 ; 50 \leq C_{P, o} \leq\right.$ $400 \mathrm{ppm}$ ) (Britto and Rangel 2008; Palma et al. 2007), being $T=45^{\circ} \mathrm{C}$ and $\mathrm{pH} 6.6$ the optimum values for tyrosinase activity (Worthington Enzyme Manual 2013), while the range of enzyme concentration studied was that $\left(25 \leq C_{T} \leq 75\right.$ $\mathrm{U} / \mathrm{mL}$ ) reported by Kameda et al. (2006). In addition, the range of rotational speed $(200 \leq N \leq$ $800 \mathrm{rpm}$ ) was selected according to Jiang et al. (2003a, b), who demonstrated the importance of this variable as well as the reaction time $(1 \leq t \leq 30$ min) to reduce the operating costs of the treatment. Since at the start of the work, a reaction time of 30 min was shown to be insufficient to reach the end of reaction, it was prolonged particularly at $T<$ $45^{\circ} \mathrm{C}$, at which the reaction was very slow. The experimental data accuracy was checked by carrying out in quadruplicate the run (n. 4) that provided the best combination of results and supposing the same reproducibility (average standard deviation of $3 \mathrm{ppm}$ ) for all the other conditions. The remaining tests were done in duplicate and the results were expressed as average values.

\section{Analytical Techniques}

The aqueous samples were analyzed for phenol concentration using a UV-VIS spectrophotometer, model DU 640 (Beckman Coulter, Brea-CA, USA), having the following features: $10 \mathrm{~mm}$ path length cuvettes; wavelength range 190-1100 nm; 4.5 to +4.5 Abs reads out to eight places and displays out four places; UV and/or VIS lamps turned off independently. At selected time intervals, $1.0 \mathrm{~mL}$-liquid samples of phenol, or $p$ nitrophenol solutions were collected from the reacting vessel by means of a syringe and filtered through cellulose acetate membranes with 0.45 $\mu \mathrm{m}$-pore diameter (Sartorius, Göttingen, Germany). The filtered samples $(300 \mu \mathrm{L})$ were transferred to the capped flasks containing $600 \mu \mathrm{L}$ of distilled water and $60 \mu \mathrm{L}$ of $8.5 \%(\mathrm{w} / \mathrm{v})$ phosphoric acid solution to inactivate the enzyme. For $o$-cresol analyses, sample and reactants volumes were twice those of the other two pollutants.

Phenol concentration was determined spectrophotometrically according to Eaton et al. (2005), as follows. $960 \mu \mathrm{L}$ of each, borate $(\mathrm{pH}=$
9.0), $0.1 \%(\mathrm{w} / \mathrm{v})$ 4-aminoantipyrine and 5\% (w/v) potassium ferricyanide solutions, were added to the samples prepared as above and the absorbance of the resulting solution was recorded at $\lambda=546$ nm exactly after $10 \mathrm{~min}$.

$p$-Nitrophenol concentration was determined similarly to phenol after the addition of $2.0 \mathrm{~mL}$ of $0.1 \mathrm{M} \mathrm{NaOH}$ solution to the samples (Toral et al. 2002). Since the $p$-nitrophenol produced yellow color in alkaline medium, the absorbance of the resulting solution was recorded at $\lambda=405 \mathrm{~nm}$, but, unlike phenol, its absorbance did not vary with time.

$o$-Cresol concentration was determined according to Neufeld and Paladino (1985). For this, the samples were supplemented with $900 \mu \mathrm{L}$ of each, $5 \%$ (w/v) ammonium chloride, $2 \%$ (w/v) 4aminoantipyrine and 29\% (w/w) ammonium hydroxide solutions, the last in order to set the $\mathrm{pH}$ at 10.0. After vigorous shaking of the mixture, 900 $\mu \mathrm{L}$ of $8 \%(\mathrm{w} / \mathrm{v})$ potassium ferricyanide were added and the absorbance of the resulting solution was recorded at $\lambda=510 \mathrm{~nm}$ exactly after $15 \mathrm{~min}$.

The concentrations of phenol, $o$-cresol and $p$ nitrophenol were determined by using blank solutions without phenols as a reference and comparing the sample absorbance with those of calibration curves previously obtained using standard specimens with known concentrations. The detection limits were $3,0.05$ and 1.25 ppm for phenol, $p$-nitrophenol and $o$-cresol, respectively.

\section{RESULTS AND DISCUSSION}

Figure 2 shows the results of phenol concentration $\left(C_{P}\right)$ versus time at different temperature and $\mathrm{pH}$ values, where those of run 4 (carried out at $T=$ $45^{\circ} \mathrm{C}$ and $\mathrm{pH}$ 6.6), which ensured the best performance, were taken as a reference. The residual phenol concentration $\left(C_{P}\right)$ and the efficiency of phenol oxidation $(\eta)$, defined as the percentage of phenol removed at the end of reaction with respect to its initial level, were not significantly influenced by the temperature in the range $25-45^{\circ} \mathrm{C}$ (Fig. $2 \mathrm{~A}$ and Table 1). On the other hand, as expected, at $T=15^{\circ} \mathrm{C} C_{P}$ reached the end of reaction only after a very long time $(t>500$ $\min )$ and the initial reaction rate $\left(-r_{o}\right)$, i.e., the slope of $C_{P}$ vs. time for $t=0$, was minimal (0.96 $\left.\mathrm{mg} \mathrm{L}^{-1} \mathrm{~min}^{-1}\right)$. It progressively increased with the temperature, reached a maximum at $T=45^{\circ} \mathrm{C}$ $\left(10.2 \mathrm{mg} \mathrm{L}^{-1} \mathrm{~min}^{-1}\right)$ and then decreased markedly 
over this threshold, likely due to thermoinactivation of the enzyme. Such a bell-shaped behavior of enzyme activity vs. temperature was already observed for most enzymatic systems, the position of the optimum activity being directly related to the temperature of maximum stability of the enzyme tertiary structure in water. For example, similar trends were observed for mycelium-bound carboxylesterases (Converti et al. 2002), lipases (Pastorino et al. 2004), dehydrogenases (Hasmann et al. 2007), proteases (Viana et al. 2010) and oxidases (Porto et al. 2006).
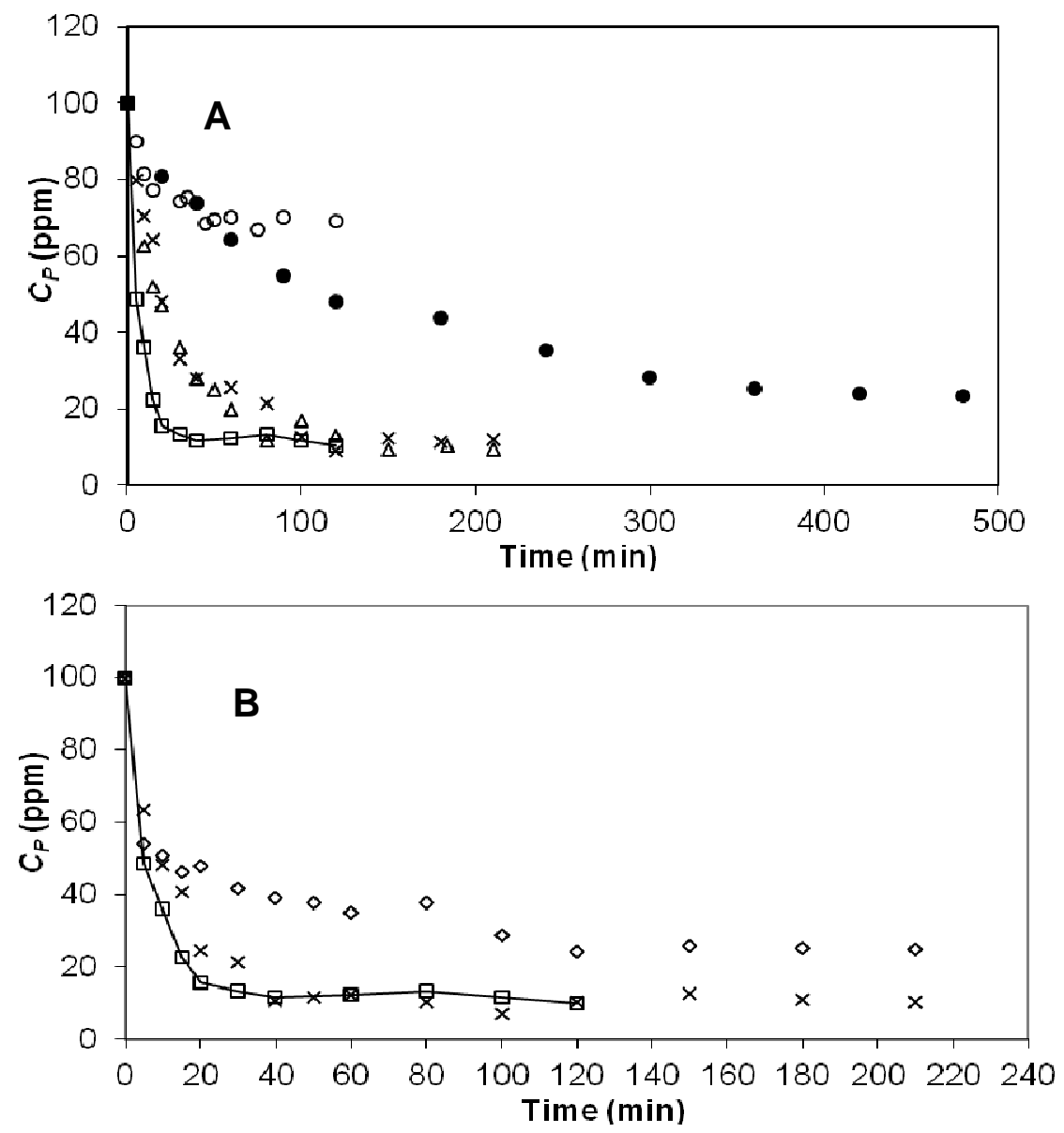

Figure 2 - Influence of (A) temperature $(T)$ and (B) $\mathrm{pH}$ on phenol oxidation by tyrosinase. Conditions: A) $N=400 \mathrm{rpm}, \mathrm{pH}=6.6, C_{T}=50 \mathrm{U} / \mathrm{mL}, C_{P, o}=100 \mathrm{ppm}$. Temperature $\left.\left({ }^{\circ} \mathrm{C}\right):(\bigcirc) 15,(\times) 25,(\triangle) 35,(-\square-) 45,(\bigcirc) 55 . \mathrm{B}\right) N=400 \mathrm{rpm}, T=45^{\circ} \mathrm{C}, C_{T}=50$ $\mathrm{U} / \mathrm{mL}, C_{P, o}=100$ ppm. pH: $(\diamond) 5.6,(-\square-) 6.6,(\times)$ 7.6. The line $(-\square-)$ represents the best conditions determined in this study $\left(T=45^{\circ} \mathrm{C}, C_{T}=50 \mathrm{U} / \mathrm{mL}, C_{P, o}=100 \mathrm{ppm}, N=\right.$ $400 \mathrm{rpm}, \mathrm{pH}=6.6$ ). The average standard deviation was about $3 \mathrm{ppm}$ for all the experimental results.

The effect of temperature on the tyrosinase activity was confirmed by the behavior of the oxidation efficiency that, as expected, exhibited a minimum value $(78.6 \%)$ at $T=15^{\circ} \mathrm{C}$, increased with temperature up to a maximum $(88.1-88.5 \%)$ in the range $25 \leq T \leq 45^{\circ} \mathrm{C}$ and then decreased to only $30.9 \%$ at $55^{\circ} \mathrm{C}$. The time to reach the end of reaction progressively decreased from more than
500 to only $25 \mathrm{~min}$ with increasing temperature from 15 to $55^{\circ} \mathrm{C}$, not only because of the above effects of temperature on enzyme activity and oxidation efficiency, but also due to better mixing and medium homogeneity owing to the resulting decrease in medium viscosity (Converti et al. 1999). Thus, the minimum $t$ value at the highest temperature was the likely result of the 
simultaneous occurrence of enzyme activity reduction, thermo-inactivation and enhanced fluid dynamics.

The $\mathrm{pH}$ influenced significantly the values of all the three responses, namely $t, \eta$ and $-r_{o}$ (Fig. 2B and Table 1). In particular, $-r_{o}$ achieved its maximum $\left(10.2 \mathrm{mg} \mathrm{L}^{-1} \mathrm{~min}^{-1}\right)$ at intermediate $\mathrm{pH}$ (6.6), whereas the minimum value of $t$ (40 $\mathrm{min}$ ) and the maximum of $\eta(89.9 \%)$ were obtained at $\mathrm{pH} \geq 6.6$ and 7.6, respectively. These results suggested that the enzyme might have been partially inactivated in the acidic environment and displayed high activity under neutral and alkaline conditions.

Even though the rotational speed had a significant impact on $\eta$ and $-r_{o}$, its influence on $t$ was small (Fig. 3A and Table 1). In particular, $-r_{o}$ exhibited a minimum value $\left(6.1 \mathrm{mg} \mathrm{L}^{-1} \mathrm{~min}^{-1}\right)$ at the lowest rotational speed $(N=200 \mathrm{rpm})$, reached a maximum (9.5-10.2 $\left.\mathrm{mg} \mathrm{L}^{-1} \mathrm{~min}^{-1}\right)$ at 300-500 rpm and then decreased beyond this threshold. On the other hand, the maximum of $\eta(88.1 \%)$ and minimum of $t$ (30-40 min) were observed at 400 and 300-500 rpm, respectively, i.e., at intermediate rotational speeds. These results confirmed that an increase in $N$ actually improved the oxidation because of improved mixing and homogeneity, but an excess agitation led to mechanical denaturation of the enzyme (Colombié et al. 2001). It was possible that the low efficiency $(69.3 \%)$ and initial oxidation rate $\left(6.1 \mathrm{mg} \mathrm{L}^{-1} \mathrm{~min}^{-1}\right)$ detected at $N=$ $200 \mathrm{rpm}$ were also the result of increased enzyme thermo-inactivation due to local superheating, but it was impossible to discriminate this effect from that of insufficient mixing.
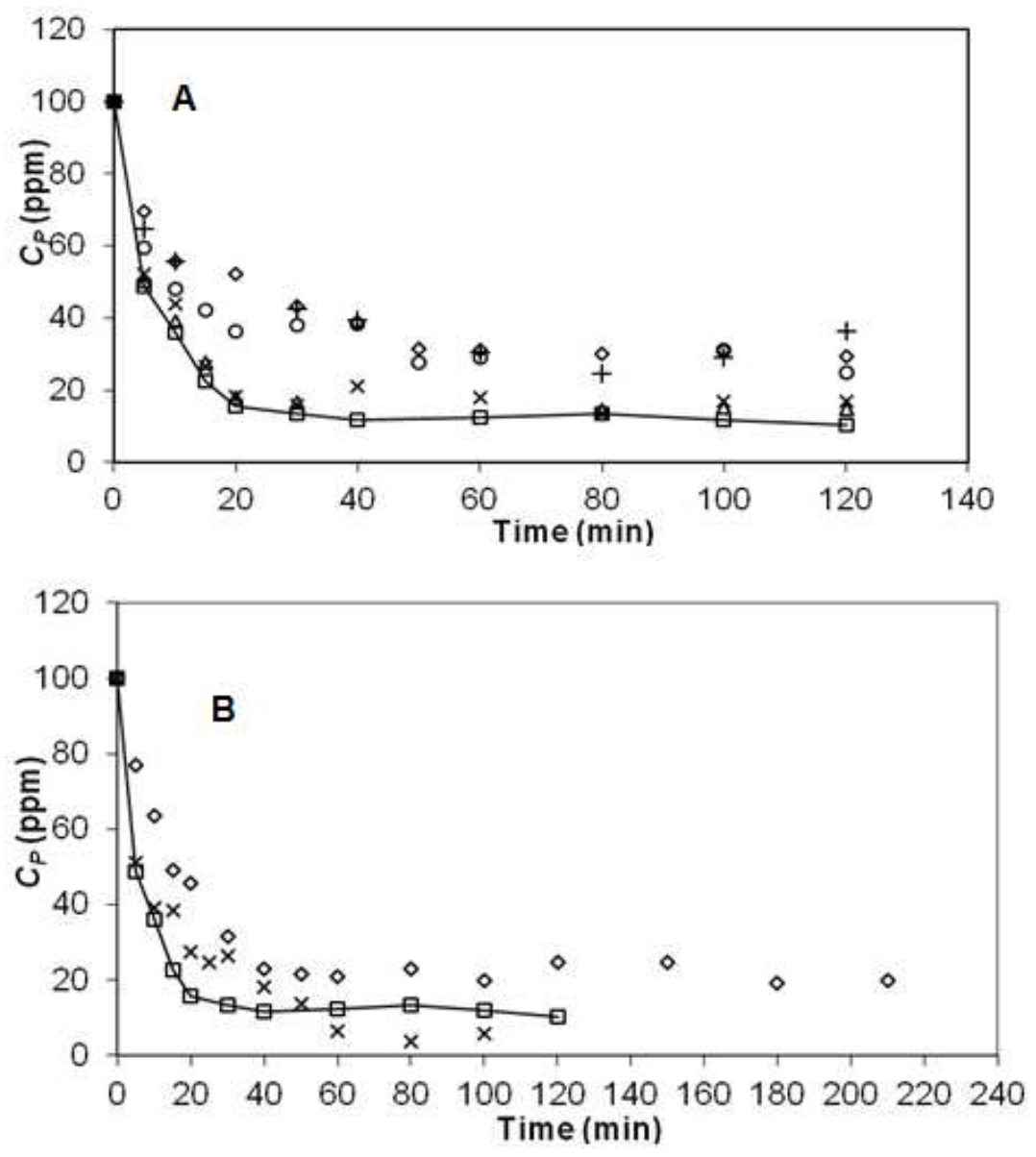

Figure 3 - Influence of $(\mathrm{A})$ the rotational speed $(N)$ and $(\mathrm{B})$ the enzyme concentration $\left(C_{T}\right)$ on phenol oxidation by tyrosinase. Conditions: A) $\mathrm{pH}=6.6, T=45^{\circ} \mathrm{C}, C_{T}=50 \mathrm{U} / \mathrm{mL}, C_{P, o}=100$

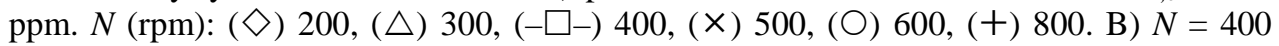
$\mathrm{rpm}, T=45^{\circ} \mathrm{C}, \mathrm{pH}=6.6, C_{P, o}=100 \mathrm{ppm} . C_{T}(\mathrm{U} / \mathrm{mL}):(\diamond) 25,(-\square-) 50,(\times) 75$. The line (- $\square-)$ represents the best conditions determined in this study $\left(T=45^{\circ} \mathrm{C}, C_{T}=50 \mathrm{U} / \mathrm{mL}\right.$, $C_{P, o}=100 \mathrm{ppm}, N=400 \mathrm{rpm}, \mathrm{pH}=6.6$ ). The average standard deviation was about $3 \mathrm{ppm}$ for all the experimental results. 
Also, the enzyme concentration $\left(C_{T}\right)$ significantly influenced the values of $t, \eta$ and $-r_{o}$ (Fig. 3B and Table 1). In particular, $-r_{o}$ reached a maximum value $\left(10.2 \mathrm{mg} \mathrm{L}^{-1} \mathrm{~min}^{-1}\right)$ at $C_{T}=50 \mathrm{U} / \mathrm{mL}$ and a minimum one $\left(4.6 \mathrm{mg} \mathrm{L}^{-1} \mathrm{~min}^{-1}\right)$ at $C_{T}=25 \mathrm{U} / \mathrm{mL}$, whereas $t$ exhibited a minimum value at $C_{T}=50$ $\mathrm{U} / \mathrm{mL}$, and $\eta$ progressively increased with $C_{T}$. These results suggested that, at $C_{T}=25 \mathrm{U} / \mathrm{mL}$ the reaction was limited by the enzyme level, while the lowest efficiency was the likely consequence of enzyme inactivation caused by the relatively high level of $o$-quinones in relation to that of the enzyme. The highest oxidation efficiency was observed at $C_{T}=75 \mathrm{U} / \mathrm{mL}$, but, surprisingly, $-r_{o}$ was lower than at $C_{T}=50 \mathrm{U} / \mathrm{mL}$, likely due to self-aggregation of the enzyme molecules at the highest level, forming clusters (dimers, trimers, oligomers) that could have made them unavailable for the catalysis. This phenomenon could have been also the reason of the surprising behavior of $t$ that showed a minimum at $C_{T}=50 \mathrm{U} / \mathrm{mL}$.

The results reported in the panel A of Figure 4 and Table 1 demonstrated that $C_{P, o}$ significantly impacted on the oxidation efficiency and the initial oxidation rate. The values of $t$ did in fact vary only from 30 to $50 \mathrm{~min}$ with increasing $C_{P, o}$ from 50 to $400 \mathrm{ppm}$, while the initial oxidation rate exhibited a bell-shaped behavior with a maximum $\left(-r_{o}=\right.$

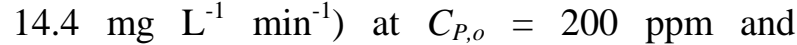
decreased over this threshold, which was typical of the well-known excess substrate inhibition observed in about $20 \%$ of the enzymes (Chaplin and Bucke 1990).
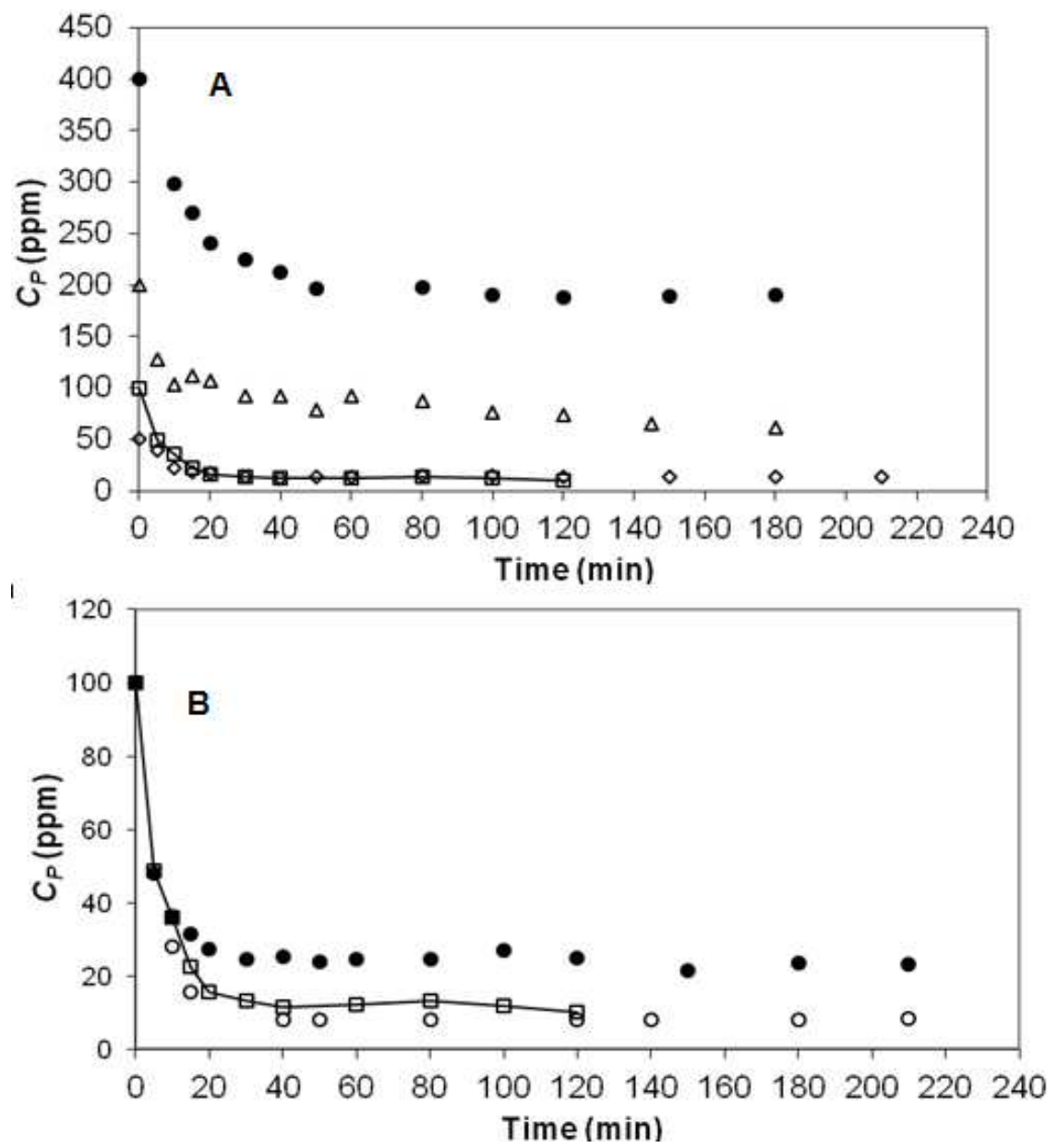

Figure 4 - A) Influence of the initial phenol concentration $\left(C_{P, o}\right)$ on phenol oxidation by tyrosinase and B) oxidation of different phenolics by tyrosinase. Conditions: A) $N=400 \mathrm{rpm}, T=$ $\left.45^{\circ} \mathrm{C}, C_{T}=50 \mathrm{U} / \mathrm{mL}, \mathrm{pH}=6.6 . C_{P, o}(\mathrm{ppm}):(\diamond) 50,(-\square-) 100,(\triangle) 200,(\bigcirc) 400 . \mathrm{B}\right) N=$ $400 \mathrm{rpm}, \mathrm{pH}=6.6, C_{T}=50 \mathrm{U} / \mathrm{mL}, C_{P, o}=100 \mathrm{ppm}, T=45^{\circ} \mathrm{C}$. (O) $p$-nitrophenol, $(\bigcirc) o$ cresol, ( $\square-$ ) phenol. The line $(-\square-)$ represents the best conditions determined in this study $\left(T=45^{\circ} \mathrm{C}, C_{T}=50 \mathrm{U} / \mathrm{mL}, C_{P, o}=100 \mathrm{ppm}, N=400 \mathrm{rpm}, \mathrm{pH}=6.6\right)$. The average standard deviation was about 3 ppm for all the experimental results. 
On the other hand, the bell-shaped curve of the oxidation efficiency suggested that this parameter could have been modulated by the inhibiting action of $o$-quinones produced by phenol oxidation. As suggested by the minimum value of this parameter $(\eta=73.0 \%)$ at $C_{P, o}=50 \mathrm{ppm}$, the lower the phenol level, the stronger was such an inhibition. An increase in phenol concentration to $100 \mathrm{ppm}$ might have accelerated the diffusion of phenol molecules towards the active site, and then led to more effective release of $o$-quinones molecules from it, thus exerting a sort of active site protection $(\eta=88.1 \%)$. However, an excess increase in $C_{P, o}(400 \mathrm{ppm})$ led to a sharp decrease in $\eta(52.0 \%)$, as the likely result of limitation of this transfer to the bulk.

The panel B of Figure 4 and Table 1 show the results of oxidation of $o$-cresol and $p$-nitrofenol (PNP) compared to phenol. It was evident that the type of substrate had little effect on both $t$ and $-r_{o}$, but strongly influenced $\eta$. The minimum and maximum values of $\eta$ were obtained with PNP and $o$-cresol, respectively, which pointed out higher affinity of tyrosinase for the hydrophilic compounds. The values of $-r_{o}$ were similar for $o$ cresol and phenol and about 30\% lower for PNP, which suggested that the increase in the electrophilicity of the aromatic ring or, more likely, in the steric hindrance, both associated to the presence of the nitro group in PNP, might have significantly reduced its reactivity.

\section{CONCLUSIONS}

This work investigated the influence of temperature $(T), \mathrm{pH}$, rotational speed $(N)$, enzyme concentration $\left(C_{T}\right)$ and initial concentration of phenol $\left(C_{P, o}\right)$ on phenol oxidation by tyrosinase in homogeneous aqueous solutions and compared these results with those obtained using $o$-cresol and $p$-nitrophenol as substrates. The process proved to be reproducible, and the results allowed properly assessing the influence of the selected variables. The optimum operating conditions were $N=400 \mathrm{rpm}, T=45^{\circ} \mathrm{C}, C_{T}=50 \mathrm{U} / \mathrm{mL}, \mathrm{pH}=6.6-$ 7.6 and $C_{P, o}=100 \mathrm{ppm}$. Although under these conditions, the final concentration of phenol in the treated solution was only $11.9 \mathrm{ppm}$, corresponding to an oxidation efficiency of $88.1 \%$, this treatment did not allow meeting the limit of $0.5 \mathrm{ppm}$ imposed for phenols by the Brazilian legislation.
Therefore, additional study would be required to increase the process efficiency. Moreover, to face the high cost of pure tyrosinase, which would make an industrial process for the treatment of wastewater contaminated by these compounds unfeasible, efforts should be made to obtain and test cheaper tyrosinase extracts of vegetable origin.

\section{ACKNOWLEDGEMENTS}

The financial support from Fundação de Amparo à Pesquisa do Estado de São Paulo (FAPESP) and Conselho Nacional de Desenvolvimento Científico e Tecnológico $(\mathrm{CNPq})$ are gratefully appreciated.

\section{REFERENCES}

Anonymous. Phenol. Chemical Week 2002; 164: 31-31. Ayranci K, Conway BE. Removal of phenol, phenoxide and chlorophenols from waste-waters by adsorption and electrosorption at high-area carbon felt electrodes. J Electroanal Chem. 2001; 513: 100-110.

Britto JM, Rangel MC. Advanced oxidation process of phenolic compounds in industrial wastewater (in Portuguese). Quim Nova. 2008; 31: 114-122.

Campeanu G, Pele M, Cimpeanu M, Ilies M, Ilies MA. Evaluation of the activity of horseradish peroxidase and mushroom polyphenoloxidase in wastewater phenol degradation process. Rom Biotech Lett. 1999; 4: 319-326.

Chaplin MF, Bucke C. Enzyme Technology. Cambridge: Cambridge University Press; 1990.

Colombié S, Gaunand A, Lindet B. Lysozyme inactivation under mechanical stirring: effect of physical and molecular interfaces. Enzyme Microb Technol. 2001; 28: 820-826.

Conselho Nacional do Meio Ambiente-CONAMA. Resolução No 357 [Internet]. Brasília: Ministério do Meio Ambiente; 2005 Mar 17 [accessed in 2013 Jun 23]. Available from: www.mma.gov.br/port/conama/ res/res05/res35705.pdf

Converti A, Del Borghi A, Gandolfi R, Lodi A, Molinari F, Palazzi E. Reactivity and stability of mycelium-bound carboxylesterase of Aspergillus oryzae. Biotechnol Bioeng. 2002; 77: 232-237.

Converti A, Zilli M, Arni S, Di Felice R, Del Borghi M. Estimation of viscosity of highly viscous fermentation media containing one or more solutes. Biochem Eng J. 1999; 4: 81-85.

Durán N, Esposito E. Potential applications of oxidative enzymes and phenoloxidase-like compounds in wastewater and soil treatment: a review. Appl Catal B-Environ. 2000; 28: 83-99. 
Eaton HD, Clesceri LS, Rice EW, Greenberg AE, Franson MAH. Standard Methods for the Examination of Water and Wastewater. Washington: American Public Health Association; 2005.

Eidhin DMN, Murphy E, O'Beirne D. Polyphenol oxidase from apple (Malus domestica Borkh. cv Bramley's Seedling): purification strategies and characterization. J Food Sci. 2006; 71: C51-C58.

Fang C, Wang C, Xiong YL, Pomper KW. Extraction and characterization of polyphenol oxidase in pawpaw (Asimira triloba) fruit. J Food Biochem. 2007; 31: 603-620.

Faria RO, Moure VR, Amazonas MALA, Krieger N, Mitchell DA. The biotechnological potential of mushroom tyrosinases. Food Technol Biotechnol. 2007; 45: 287-294.

Freire RS, Pelegrini R, Kubota LT, Durán N. New trends for treatment of industrial effluents containing organochloride species (in Portuguese). Quim Nova. 2000; 23: 504-511.

Fuerst EP, Anderson JV, Morris CF. Polyphenol oxidase in wheat grain: whole kernel and bran assays for total and soluble activity. Cereal Chem. 2006; 83: 10-16.

Hasmann FA, Gurpilhares DB, Roberto IC, Converti A, Pessoa Jr A. New combined kinetic and thermodynamic approach to model glucose-6phosphate dehydrogenase activity and stability. Enzyme Microb Technol. 2007; 40: 849-858.

Ikehata K, Nicell JA. Characterization of tyrosinase for the treatment of aqueous phenols. Bioresour Technol. 2000a; 74: 191-199.

Ikehata K, Nicell JA. Color and toxicity removal following tyrosinase-catalyzed oxidation of phenols. Biotechnol Prog. 2000b; 16: 533-540.

Jain AK, Bhatnagar S, Bhatnagar A. Methylphenols removal from water by low-cost adsorbents. J Colloid Interface Sci. 2002; 251: 39-45.

Jiang H, Fang Y, Fu Y, Guo QX. Studies on the extraction of phenol in wastewater. $J$ Hazard Mater. 2003a; 101: 179-190.

Jiang H, Tang Y, Fu Y, Guo QX. Separation and recycle of phenol from wastewater by liquid-liquid extraction. Sep Sci Technol. 2003b; 38: 2579-2596.

Kameda E, Langone MAP, Coelho MAZ. Tyrosinase extract from Agaricus bisporus mushroom and its in natura tissue for specific phenol removal. Environ Technol. 2006; 27: 1209-1215.

Kujawski W, Warszawski A, Ratajczak W, Porębski T, Capała W, Ostrowska I. Removal of phenol from wastewater by different separation techniques. Desalination. 2004; 163: 287-296.

López-Molina D, Hiner ANP, Tudela J, GarcíaCánovas F, Rodríguez-López JN. Enzymatic removal of phenols from aqueous solution by artichoke (Cynara scolymus L.) extracts. Enzyme Microb Technol. 2003; 33: 738-742.
Martin LB, Nikodinovic J, Mc Mahon AM, Vijgenboom E, O'Connor KE. Assessing the catalytic activity of three different sources of tyrosinase: a study of the oxidation of mono- and difluorinated monophenols. Enzyme Microb Technol. 2008; 43: 297-301.

Mojović Z, Milutinović-Nikolić A, Mentus S, Jovanović D. Electrochemical oxidation of phenol on metal-impregnated zeolite electrodes. Chem Eng Technol. 2009; 32: 738-744.

Neufeld RD, Paladino SB. Comparison of 4aminoantipyrine and gas-liquid chromatography techniques for analysis of phenolic compounds. $J$ Water Pollut Control Fed. 1985; 57: 1040-1044.

Palma MSA, Paiva JL, Zilli M, Converti A. Batch phenol removal from methyl isobutyl ketone by liquid-liquid extraction with chemical reaction. Chem Eng Process. 2007; 46: 764-768.

Palma MSA, Shibata C, Paiva JL, Zilli M, Converti A. Batch liquid-liquid extraction of phenol from aqueous solutions. Chem Eng Technol. 2010; 33: 39-43.

Pastorino L, Pioli F, Zilli M, Converti A, Nicolini C. Lipase-catalyzed degradation of poly( $\varepsilon$-caprolactone). Enzyme Microb Technol. 2004; 35: 321-326.

Porto TS, Porto CS, Cavalcanti MTH, Lima Filho JL, Perego P, Porto ALF, et al. Kinetic and thermodynamic investigation on ascorbate oxidase activity and stability of a Cucurbita maxima extract. Biotechnol Prog. 2006; 22: 1637-1642.

Quadros PA, Baptista CMSG. Effective interfacial area in agitated liquid-liquid continuous reactors. Chem Eng Sci. 2003; 58: 3935-3945.

Quan D, Kim Y, Shin W. Sensing characteristics of tyrosinase immobilized and tyrosinase, laccase coimmobilized platinum electrodes. Bull Korean Chem Soc. 2004; 25: 1195-1201.

Romanovskaya II, Shesterenko YA, Sevast'yanov OV. Elimination of phenol with the use of tyrosinase of fungi. J Water Chem Technol. 2009; 3: 135-138.

Rosatto SR, Freire RS, Durán N, Kubota LT. Amperometric biosensors for phenolic compounds determination in the environmental interest samples (in Portuguese). Quim Nova. 2001; 24: 77-86.

Sellés-Marchart S, Casado-Vela J, Bru-Martínez R. Isolation of a latent polyphenol oxidase from loquat fruit (Eriobotrya japonica Lindl.): kinetic characterization and comparison with active form. Arch Biochem Biophys. 2006; 446: 175-185.

Shibata CT, Palma MSA. Recovery of priority pollutants from aqueous solutions through liquidliquid extraction with simultaneous treatment of acid gases. Chem Eng T. 2009; 18: 285-290.

Theodore L, Buonicore AJ, McKenna JD, Kugelman IJ, Jeris JS, Santoleri JJ, et al. Waste management. In: Perry RH, Maloney JO, editor. Perry's Chemical Engineer's Handbook. New York: McGraw-Hill; 1997. p. 25.1-25.111. 
Toral MI, Beattie A, Santibañez C, Richter P. Simultaneous determination of parathion and $p$ nitrophenol in vegetable tissues by derivative spectrophotometry. Environ Monit Assess. 2002; 76: 263-274.

Viana DA, Lima CA, Neves RP, Mota CS, Moreira KA, Cavalcanti MTH, et al. Production and stability of protease from Candida buinensis. Appl Biochem Biotechnol. 2010; 162: 830-842.

Worthington Enzyme Manual. Polyphenol oxidase [Internet]. Lakewook, NJ: Worthington Biochemical Corporation; 2013 [accessed in 2013 Jun 23]. Available from: http://www.worthingtonbiochem.com/TY/default.html.
Wuyts N, Waele DD, Swennen R. Extraction and partial characterization of polyphenol oxidase from banana (Musa acuminate Grande naine) roots. Plant Physiol Biochem. 2006; 44: 308-314.

Yamada K, Tamura T, Azaki Y, Kashiwada A, Hata Y, Higashida K, et al. Removal of linear and branched $p$ alkylphenols from aqueous solution by combined use of melB tyrosinase and chitosan beads. J Polym Environ. 2009; 17: 95-102.
Received: January 26, 2012; Accepted: June 18, 2013. 